\title{
Differences in population structure and growth rate of the stalked barnacle Pollicipes polymerus between a rocky headland and an offshore oil platform
}

\author{
Henry M. Page \\ Marine Science Institute, University of California, Santa Barbara, California 93106, USA
}

\begin{abstract}
Population structure and growth rate of the stalked barnacle Pollicipes polymerus Sowerby differed between a rocky headland along protected outer coast (Goleta Point, Santa Barbara, California) and the supports of an $18 \mathrm{yr}$ old oil production platform (Holly, ARCO) located $3 \mathrm{~km}$ offshore. The population structure at Goleta Pt. was positively skewed, with a maximum individual size of $26 \mathrm{~mm}$ capitulum height $(\mathrm{CH})$. The population structure at Holly was distinctly bimodal, with a maximum individual size of $36 \mathrm{~mm} \mathrm{CH}$. The differences in maximum size were attributable to the much faster growth rate of offshore barnacles. A. P. polymerus at $10 \mathrm{~mm} \mathrm{CH}$ grew $0.114 \mathrm{~mm} \mathrm{~d}^{-1}$ at Holly compared with $0.033 \mathrm{~mm} \mathrm{~d}^{-1}$ at Goleta Pt. The skewed size distribution at Goleta Pt. was due to poor long-term survival, in part because of erosion of the soft shale rock substratum. The age of the platform, the stability of the pipe substratum, and intraspecific competition contributed to the bimodal size distribution of the offshore population. The factors which influence the growth and survival of $P$. polymerus at Holly may similarly influence these characteristics in other invertebrate species at the same offshore location.
\end{abstract}

\section{INTRODUCTION}

Local environmental conditions and phenotypic plasticity influence the population and life history characteristics of barnacles. In particular, studies have demonstrated the potential for variability in rates of growth (e.g. Barnes \& Powell 1953, Barnes 1956, Crisp 1960), reproduction (e.g. Barnes \& Barnes 1968, Lewis \& Chia 1981, Page 1984), recruitment and mortality (e.g. Connell 1961, 1970, Dayton 1971, Hines 1976) of barnacles as a function of intertidal location.

The stalked barnacle Pollicipes polymerus Sowerby is gregarious and typically found in the mid-intertidal zone on exposed rocky shores and on the supports of piers and offshore structures. The growth form of aggregations of $P$. polymerus is 'bush-like' (Connell \& Keough 1985). Each barnacle adds, with a stalk length of up to 5 or more centimeters, a vertical as well as horizontal structural component to intertidal communities during growth.

Considerable variation in maximum size and population structure of this species can exist among locations. The present study revealed that populations of Pollicipes polymerus differed substantially between 2 proximal, but spatially separated locations: the rocky intertidal zone at Goleta Point (Santa Barbara, California, USA), a headland along protected outer coast, and the supports of an 18 yr old oil and natural gas production platform located $3 \mathrm{~km}$ offshore (ARCO platform 'Holly'). The most obvious differences between barnacles in these 2 localities were in population structure and maximum individual size. $P$. polymerus attained much larger sizes at the offshore location.

The inshore and offshore locations occupied by Pollicipes polymerus in this study were approximately the same tidal height, but differed in the nature of the 
substratum, the type of wave exposure, and perhaps food availability. This study documented differences in population structure, growth rate, and the size and age at onset of egg production of $P$. polymerus between the 2 sites.

\section{MATERIALS AND METHODS}

Study sites. The rocky intertidal study site at Goleta Pt. $\left(34^{\circ} 25^{\prime} \mathrm{N}, 119^{\circ} 52^{\prime} \mathrm{W}\right)$ receives considerable wave shock, backwash, and surge. Pollicipes polymerus, restricted to specific habitats characterized by a high degree of turbulence (Barnes \& Reese 1959), is abundant at this location. I chose a vertical rock face protected from direct wave shock and occupied by the largest $P$. polymerus as the study area at Goleta Pt. $P$. polymerus covered $\sim 70 \%$ of the rock substratum. A few mussels (Mytilus californianus) were also present. The offshore study site was located on the vertical and horizontal support members of an oil and natural gas production platform 'Holly' (ARCO), which had not been cleaned of organisms prior to this study. $P$. polymerus, along with mussels (Mytilus californianus, $M$. edulis), acorn barnacles (Tetraclita rubescens, Megabalanus californicus), and sea anemones (Anthopleura elegantissima) covered $\sim 95 \%$ of the pipe surface in the mid-intertidal region of the supports. Large clumps of $P$. polymerus were patchily distributed. The designated study area at Holly, however, was almost entirely covered by these barnacles. A single sample collection of $P$. polymerus was also made by J. MacDonald from a support member of Platform Henry (Sun), an oil production platform located $8 \mathrm{~km}$ offshore of Carpinteria, California $135 \mathrm{~km}$ east of Santa Barbara), which had not been cleaned of fouling organisms within the previous $5.5 \mathrm{yr}$.

Field samples. I collected samples of Pollicipes polymerus from a tidal height of approximately +0.15 to $0.30 \mathrm{~m}$ MLLW (estimated from a Pacific Towboat and Salvage tidal calendar, Long Beach, California) at Goleta Pt. and at Holly. Once every 2 mo from November 1983 to September 1984, two $15 \times 15 \mathrm{~cm}$ quadrats were placed at random along a horizontal transect line marked in $15 \mathrm{~cm}$ segments in the intertidal study areas of both Goleta Pt. and Holly. All $P$. polymerus within the quadrats were collected. To determine the population size structure, I measured the capitulum height (vertical distance from the base of the accessory plates to the tip of the terga, hereafter $\mathrm{CH}$ ) of all barnacles. I also determined the percentage of barnacles carrying egg masses as a function of size at the 2 localities. The size of egg-bearing $P$. polymerus was determined by inspecting a large size range of individuals for the presence of egg masses in the mantle cavity in samples taken during the peak of breeding activity (Feb, Apr, late May) (Straughan 1971, Page 1984). The soft tissues of some specimens taken in November and February from Goleta Pt. and in November, February, April, and August from Holly were removed and dried at $60^{\circ} \mathrm{C}$ to constant weight to determine the capitulum height versus soft tissue weight relation at each location. I determined only the population size structure, by measuring capitulum height, of the single collection from Platform Henry, taken in July 1984.

Growth rate. The growth rate of Pollicipes polymerus at Goleta Pt. was determined by marking groups of barnacles and measuring individuals over a $10 \mathrm{mo}$ period. On a vertical rock face at Goleta Pt., 16 clumps of barnacles $\left(x=2.5 \pm 1.4 \mathrm{SD}\right.$ barnacles clump ${ }^{-1}$, $\mathrm{n}=40$ barnacles) with a mean size range of from 3 to $16 \mathrm{~mm} \mathrm{CH}$ were marked in January 1984 by gluing a numbered stainless steel washer adjacent to the clumps with underwater epoxy (Devcon). More than one clump could be marked with one washer by recording distance and 'clock heading' of the clump from the washer. I measured the capitulum height of identified $P$. polymerus, to the nearest $0.5 \mathrm{~mm}$, every 2 to $4 \mathrm{wk}$.

Few small Pollicipes polymerus were available for marking at Holly. I used 2 approaches to measure barnacle growth rate at this location. First, groups of $P$. polymerus with a mean size range of from 4 to $15 \mathrm{~mm}$ $\mathrm{CH}$ were transplanted from Goleta Pt. to Holly in January ( 3 clumps, $\bar{x}=5.0 \pm 2.6$ bamacles clump ${ }^{-1}$, $\mathrm{n}=15$ ) and in March ( 3 clumps, $\overline{\mathrm{x}}=7.3 \pm 1.5$ barnacles clump ${ }^{-1}, n=22$ ). Barnacles from Goleta Pt., attached either to rock or mussel shell, were glued with epoxy to the platform supports in the intertidal zone. I orientated the feeding apparatus of the transplanted $P$. polymerus in the same direction as that of the resident large individuals. Second, I marked 7 clumps of resident barnacles $(\overline{\mathrm{x}}=1.9 \pm 0.4$ barnacles clump $^{-1}, \mathrm{n}=14$ ) with a mean size range of from 6 to $30 \mathrm{~mm} \mathrm{CH}$ in March 1984 with stainless steel washers and measured their change in capitulum height over time. To identify potential sources of barnacle mortality, I monitored the survival of 40 marked $P$. polymerus at Goleta Pt. and 14 marked resident $P$. polymerus at Holly.

Competition experiment. On Platform Holly, I examined whether the growth of small Pollicipes polymerus might be inhibited by the large $P$. polymerus. I removed barnacles $>16 \mathrm{~mm} \mathrm{CH}$ in a $100 \mathrm{~cm}^{2}$ treatment plot $100 \%$ covered with $P$. polymerus. Barnacles were removed by cutting the stalk with a scalpel, a few millimeters from the substratum, which revealed the smaller $(<12 \mathrm{~mm} \mathrm{CH}$ ) barnacles. The exposed small barnacles were counted and measured. An adjacent unmanipulated plot $\left(100 \mathrm{~cm}^{2}\right)$ served as a control. After $98 \mathrm{~d}$ (20 May to 26 Aug 1984), I collected and sepa- 
rately measured the size of barnacles in both treatment and control plots.

\section{RESULTS}

\section{Population size structure}

No significant changes in population size structure occurred over time at either Goleta Pt. or Platform Holly ( $P>0.05$, Kolmogrov-Smirnov test, Sokal \& Rohlf 1981). The grouped data for each locality are given in Fig. 1. The population structure of Pollicipes polymerus at Goleta Pt. was positively skewed with few barnacles larger than $22 \mathrm{~mm} \mathrm{CH}$ and no barnacles larger than $26 \mathrm{~mm} \mathrm{CH}$ (Fig. 1a). In contrast, the population structure of $P$. polymerus at Holly was distinctly bimodal and significantly different from that at Goleta Pt. ( $\mathrm{P}<0.05$, Kolmogrov-Smirnov test) (Fig. 1b). The offshore population consisted of a mode at $10 \mathrm{~mm} \mathrm{CH}$ and a mode at 26 to $30 \mathrm{~mm} \mathrm{CH}$ with a maximum individual barnacle size of $36 \mathrm{~mm} \mathrm{CH}$. The population structure of $P$. polymerus in the single sample from Platform Henry was also bimodal (modes at $10 \mathrm{~mm}$ and $30 \mathrm{~mm} \mathrm{CH}$ ) with a maximum individual size of $34 \mathrm{~mm}$ $\mathrm{CH}$ (Fig. 2).

\section{Height-weight relation}

There was no difference in the log capitulum height versus log soft tissue dry weight relation for Pollicipes polymerus between sample dates at each locality or between localities ( $P>0.1$, ANCOVA) (Fig. 3). A log transformation of capitulum height and of tissue dry weight prior to regression analysis provided a higher linear correlation between these 2 variables over a large size range of barnacles than the relation between cube of capitulum height and soft tissue dry weight calculated in Page (1984).

\section{Size-specific growth rate}

The data on the rate of growth of Pollicipes polymerus at Goleta Pt. and at Holly are expressed as the change in capitulum height per day, calculated over 2 to $4 \mathrm{wk}$ periods, as a function of initial barnacle size (Fig. 4). Some points are not completely independent of one another as they represent more than one measure of the same individuals over time. A least-squares logarithmic regression curve $(y=a-b \ln x)$ was computed through the points from each locality. The logarithmic equation was chosen over power and exponential equations because it more accurately fit the points in the smaller size classes and y could be set



Fig. 1. Pollicipes polymerus. Population size structure at (a) Goleta Pt. and (b) Holly. Data grouped for samples taken bimonthly, Nov 1983 to Sep 1984

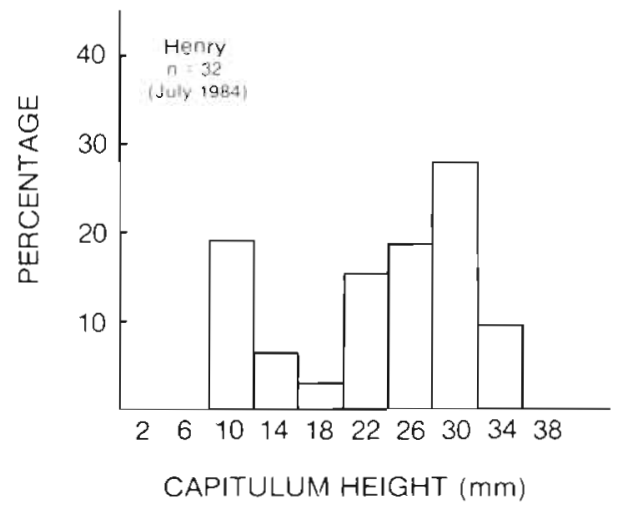

Fig. 2. Pollicipes polymerus. Population size structure at Henry in Jul 1984

to 0 , permitting an estimate of maximum attainable size (i.e. when growth $=0$ ).

At Holly, no significant difference in size-specific growth rate was found between resident and transplanted barnacles ( $P>0.1$, ANCOVA) (Fig. 4). A significant difference in growth rate, however, existed between the Pollicipes polymerus at Goleta Pt. and at Holly $(\mathrm{P}>0.1$ for difference in slopes, $\mathrm{P}<0.001$ for difference in elevations, ANCOVA). For example, the growth rate of individuals with a capitulum height of $10 \mathrm{~mm}$ was $0.114 \mathrm{~mm} \mathrm{~d}^{-1}$ at Holly compared with 


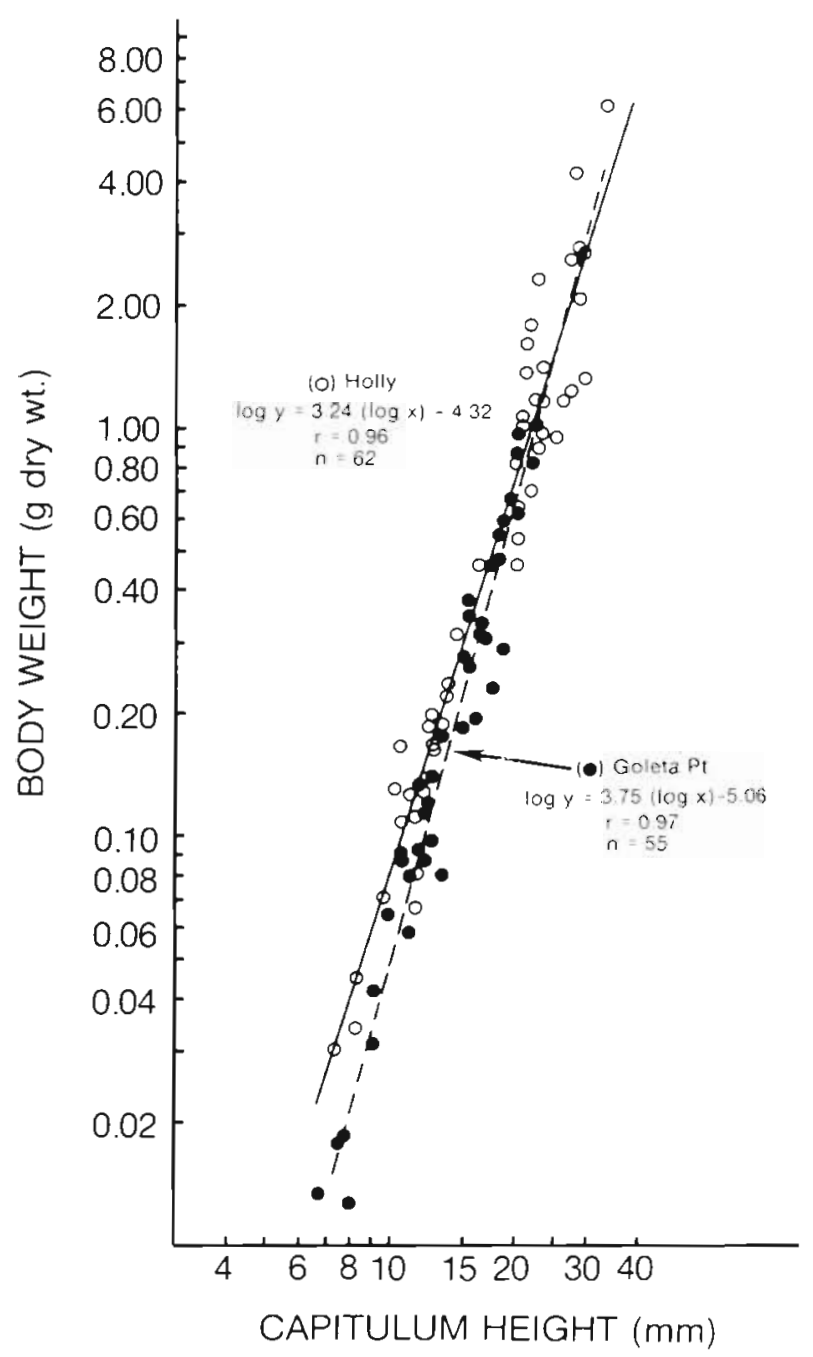

Fig. 3. Pollicipes polymerus. Linear regression of log body weight on log capitulum height for specimens from Goleta Pt. and Holly. Data grouped by location

$0.033 \mathrm{~mm} \mathrm{~d}^{-1}$ at Goleta Pt. The growth rate at Goleta Pt. was not significantly different ( $P>0.1$, ANCOVA) from that measured several years earlier at the same tidal height (Fig. 4).

The accuracy of the regression equations was determined by setting $y=0$ and solving for $x$ in the equation $\mathrm{y}=\mathrm{a}-\mathrm{b} \ln \mathrm{x}$ which should provide an estimate of the maximum size attainable by Pollicipes polymerus at each location. The values of $20 \mathrm{~mm} \mathrm{CH}$ at Goleta Pt. and $35 \mathrm{~mm} \mathrm{CH}$ at Holly compare favorably with the maximum sizes of $26 \mathrm{~mm}$ and $36 \mathrm{~mm} \mathrm{CH}$ observed at each location.

Of the 40 Pollicipes polymerus alive in late January at Goleta Pt., 10 individuals (25\%) remained after $19 \mathrm{wk}$. Of the 14 residents followed at Holly, 11 individuals ( $79 \%$ ) remained after $17 \mathrm{wk}$. Barnacle mortality at Goleta Pt. was due primarily to the 'catastrophic' loss of clumps rather than from the death of individuals

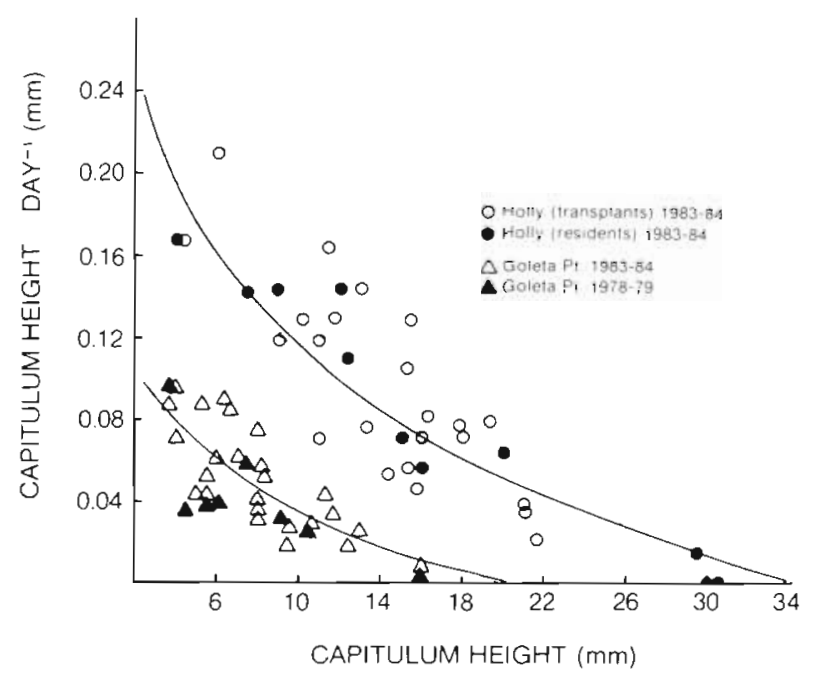

Fig. 4. Pollicipes polymerus. Size-specific growth curves at Goleta Pt. and at Holly. A least-squares logarithmic regression curve was computed through the points. Goleta Pt.: $\mathrm{y}=0.141-0.047 \ln \mathrm{x}, \mathrm{r}=0.73, \mathrm{n}=39$. Holly: $\mathrm{y}=$ $0.326-0.092 \ln x, r=0.84, n=37$

within clumps. In late January, 4 clumps (12 individuals) disappeared. Little further mortality occurred until May when 4 more clumps (15 individuals) disappeared. I found patches of newly exposed rock surface at the former location of the marked clumps.

\section{Growth curve}

Growth curves for Pollicipes polymerus at the 2 localities (Fig. 5) were constructed from size-specific growth increments derived from the equations in Fig. 4. Actual growth, measured from a size of 7 to $9 \mathrm{~mm} \mathrm{CH}$ for up to $10 \mathrm{mo}$, is also shown in Fig. 5. These growth curves predict that $P$. polymerus at Goleta Pt.

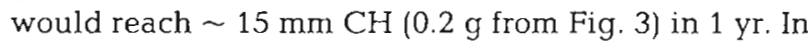
contrast, $P$. polymerus at the platform rapidly increase in size reaching $\sim 25 \mathrm{~mm} \mathrm{CH}(1.6 \mathrm{~g})$ in 1 yr. After $5 \mathrm{yr}$, P. polymerus would achieve a size of $\sim 20 \mathrm{~mm} \mathrm{CH}$ $(0.7 \mathrm{~g})$ at Goleta Pt. and $\sim 34 \mathrm{~mm} \mathrm{CH}(4.4 \mathrm{~g})$ at Holly. The largest $P$. polymerus at Platform Henry, which had been cleaned 5.5 yr previously, were 31 to $34 \mathrm{~mm} \mathrm{CH}$ supporting the conclusion that this size could be attained in $5 \mathrm{yr}$ at Holly. The data on population size structure (Fig. 1) and the growth curves (Fig. 5) indicate that, in the study area at Goleta Pt., only $8 \%$ of the population of $P$. polymerus were $>2$ yr old. At Holly, at least $30 \%$ of the population was $>2$ yr old.

\section{Competition experiment}

The size distribution of Pollicipes polymerus in the Treatment plot, before removal of the large barnacles, 
Fig. 5. Pollicipes polymerus. Growth curves at Goleta Pt. and at Holly computed from the data in Fig. 4. Circles represent mean values of barnacles which were continuously followed from a size of 7 to $9 \mathrm{~mm} \mathrm{CH}$ for up to $10 \mathrm{mo}$. Sample sizes: Goleta Pt. (closed circles), $n=12$; Holly (open circles), $\mathrm{n}=15$

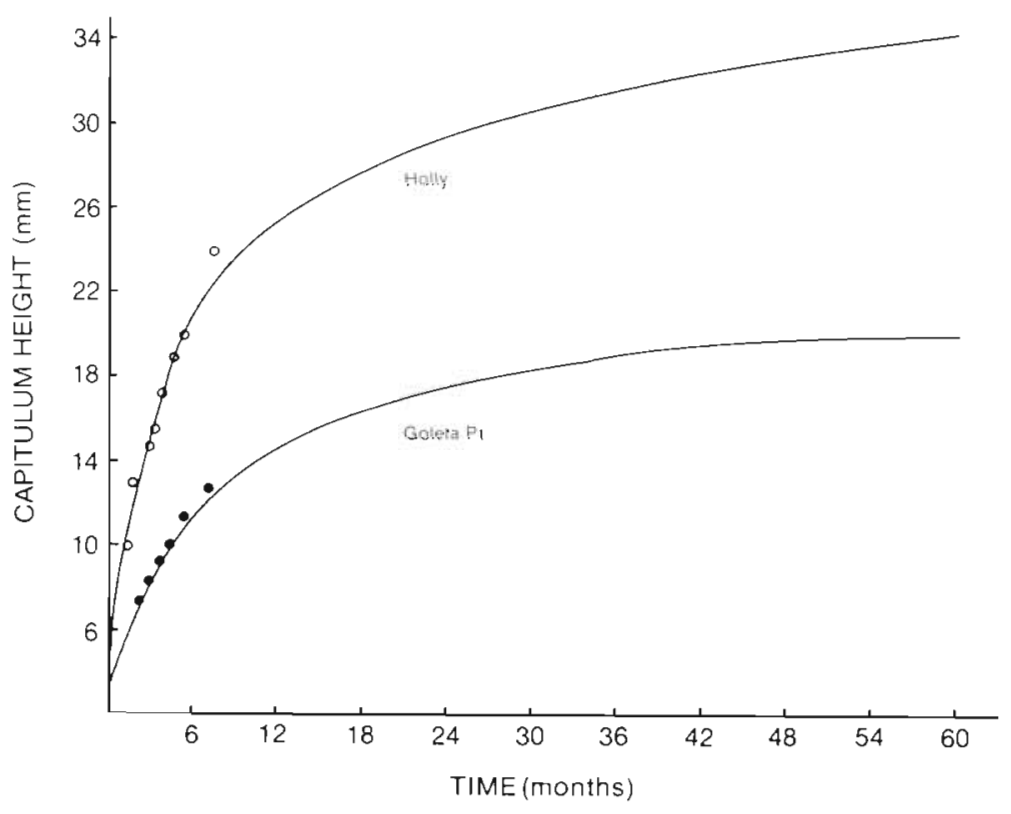

Treatment plot were significantly larger than their initial size and the size of small barnacles in the Control plot $(\mathrm{P}<0.01$, Mann-Whitney $\mathrm{U}$ test $)$. The increase in size of $4 \mathrm{~mm} \mathrm{CH}$ (from 10 to $14 \mathrm{~mm} \mathrm{CH}$ ) was approximately half that predicted from the growth curve (Fig. 5): a P. polymerus of $10 \mathrm{~mm} \mathrm{CH}$ could grow $4 \mathrm{~mm}$ in $45 \mathrm{~d}$.

\section{Size and age at onset of reproduction}

The percentage of Pollicipes polymerus with egg masses at Goleta Pt. and at Holly increased with increase in barnacle size (Fig. 7). The size at which $>50 \%$ of barnacles carried egg masses was $16 \mathrm{~mm}$ $\mathrm{CH}$ at Goleta Pt. and $28 \mathrm{~mm} \mathrm{CH}$ at Holly. The smallest barnacles carrying egg masses were $12 \mathrm{~mm} \mathrm{CH}$ at Goleta Pt. and $16 \mathrm{~mm} \mathrm{CH}$ at Holly. From the growth curves in Fig. 5, P. polymerus may produce egg masses after $175 \mathrm{~d}$ at Goleta Pt. and after $100 \mathrm{~d}$ at Holly.

\section{DISCUSSION}

The difference in maximum individual size of $\mathrm{Pol}$ licipes polymerus between Goleta Pt. and Holly resulted from the difference in rate of growth of barnacles in these 2 localities. Indeterminate growth is a characteristic feature of many invertebrate species, where the upper size limit of an organism is set by growth rate, which in turn is determined by local environmental conditions (e.g. Ebert 1968, Paine 1976, Kantsky 1982, Sebens 1982). The maximum size of $P$.
Fig. 6. Pollicipes polymerus. Results of competition experiment. Top: size distribution in Treatment plot on 20 May; barnacles in the upper mode (broken line) were removed. Centre: shaded bars indicate location of the mode of smaller barnacles on 26 Aug. Bottom: size distribution of barnacles in Control plot, determined on 26 Aug 


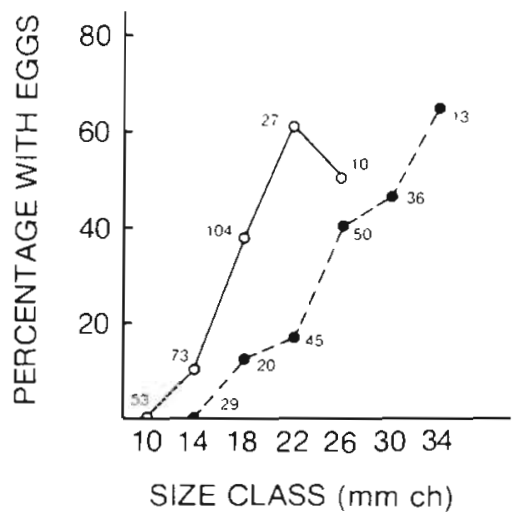

Fig. 7. Pollicipes polymerus. Percentage carrying egg masses as a function of size. Numbers indicate sample size. Open circles: Goleta Pt.; closed circles: Holly

polymerus at Goleta Pt. did not change during the year, but these barnacles retained the capability to grow and, when transplanted to Holly, achieved a growth rate comparable to that of resident platform barnacles. Studies of other organisms have also found a similar response of growth rate to changes in local environmental conditions. Paine (1976) transplanted starfish Pisaster ochraceus from populations with an apparent invariant small mean size to habitats with more available food and observed that maximum body size did not reach a locally imposed terminal limit, but would increase under conditions of more food. Mussels Mytilus edulis transplanted from the high and midshore regions of an exposed rocky shore to continuously submerged conditions in a sheltered harbor showed increased growth rates (Seed 1968). Fletcher (1984) also found that the growth rate of individuals from intertidal populations of the limpet Cellana tramoserica increased after transplantation from intertidal to subtidal locations.

Bourget \& Crisp (1975) described food availability as the most important factor influencing the growth rate of barnacles. The variation in rate of growth of Pollicipes polymerus observed between the inshore and offshore locations in this study is thus likely due to local differences in food availability, Vertical location in the intertidal zone can influence the growth rate of sessile or relatively non-motile filter-feeding organisms (e.g. Barnes \& Powell 1953). Barnacles experience more submergence time when located lower in the intertidal zone and consequently can feed longer, resulting in faster growth rates (Barnes \& Powell 1953). This explanation does not apply in the present study, however, because bamacles at the 2 study sites were located at approximately the same tidal height. Spatial variation in the food available to animals at the same tidal height may result from differences in the quality or quantity of food in the water and/or current patterns which bring available food to sessile animals.

Rodhouse et al. (1984) postulated that food availability may have been responsible for the difference in the rate of growth of the mussel Mytilus edulis on the rocky shore compared with offshore rafts. These authors found that the food available to inshore mussels during the summer was of lower nutritional value (a mixture of phytoplankton and detritus) than that available to offshore mussels (primarily phytoplankton). No data are available on the quantity of food available to Pollicipes polymerus. However, the guts of inshore barnacles, in contrast to offshore barnacles, typically contain sand (pers. obs.), suggesting that food quality differed between the 2 locations. While considerable sand is suspended in the surf at Goleta Pt., the platform is located in water $60 \mathrm{~m}$ deep and bottom sediments are not present near the surface. Rodhouse et al. (1984) also postulated that differences in current flow and wave action between inshore and offshore localities may have influenced growth rate. The $P$. polymerus attached to the supports at Holly experience vigorous water motion from currents and passing swell, but are not subjected to the pounding wave shock of barnacles at Goleta Pt. High levels of wave impact are detrimental to the growth of some species (e.g. the mussel Mytilus edulis: Harger 1970).

A comparison of the results of Paine (1974) and Lewis \& Chia (1981) from northern Washington, USA, with those of the present study, failed to show a latitudinal trend in the growth rate of Pollicipes polymerus. The growth rate of $P$. polymerus at Holly was faster, however, than rates reported in the literature. $P$. polymerus at Tatoosh Island, Washington, achieved a size of $\sim 35 \mathrm{~mm} \mathrm{RC}$ (rostralcarinal diameter: equivalent to 26 to $27 \mathrm{~mm} \mathrm{CH}$, using the capitulum height-width equation in Page 1984) after $72 \mathrm{mo}$. The mean size $1 \mathrm{yr}$ following settlement of these $P$. polymerus ( $18 \mathrm{~mm} \mathrm{RC}$, 14 to $15 \mathrm{~mm} \mathrm{CH}$ ) was similar to the size of $1 \mathrm{yr}$ old individuals at Goleta Pt. Lewis \& Chia (1981) found $P$. polymerus reached 11 to $15 \mathrm{~mm} \mathrm{RC} \mathrm{(9} \mathrm{to} 12 \mathrm{~mm} \mathrm{CH}$ ) in 1 yr at San Juan Island, Washington. They observed little growth of barnacles $\sim 30 \mathrm{~mm} \mathrm{RC} \mathrm{(23} \mathrm{to} 24 \mathrm{~mm}$ $\mathrm{CH}$ ) (Lewis \& Chia 1981).

In addition to differences in growth rate, the size at the onset of reproduction of Pollicipes polymerus differed between inshore and offshore populations. The size of the smallest $P$. polymerus carrying egg masses and the size at which $>50 \%$ of the barnacles carried egg masses were larger at Holly than at Goleta Pt. Lewis \& Chia (1981) also found faster barnacle growth rates associated with a larger size of animals carrying egg masses at San Juan Island, Washington. The age at the onset of reproduction for $P$. polymerus at Goleta Pt. and Holly agree more closely with estimates of 12 to 
36 mo at San Juan Island (Lewis \& Chia 1981) than with the estimate of $5 \mathrm{yr}$ for individuals at Pt. Dune, southern California (Barnes \& Reese 1959). Three lines of evidence indicate that the lifetime fecundity of an individual $P$. polymerus is potentially greater at Holly than at Goleta Pt. First, $P$. polymerus attain larger sizes at Holly than at Goleta Pt. (Fig. 1). They thus produce larger egg masses, since egg mass size increases with body size at both locations (Page 1984, unpubl. data to a size of $34 \mathrm{~mm} \mathrm{CH}$ ). Second, barnacles produce eggs earlier in life at Holly than at Goleta Pt. (Fig. 5 \& 7). Third, barnacles can survive longer and thus produce egg masses over a longer period of time at Holly than at Goleta Pt. (Fig. 1 \& 5).

The population of Pollicipes polymerus at Goleta Pt. possessed a higher proportion of individuals in the smallest size class compared with the population at Holly (Fig. 1). There was no evidence of a strongly seasonal period of recruitment or of well-defined size or age classes characteristic of other barnacle species or populations along the California coast (e.g. Balanus glandula, Barnes \& Barnes 1956, Hines 1979, Tetraclita squamosa, Hines 1979). I suggest 3 possible explanations to account for the higher percentage of small barnacles at Goleta Pt. than at Holly. First, greater numbers of $P$. polymerus cyprids may be distributed inshore compared with offshore. The differential distribution of the larvae of some barnacle species in the water column and by location has been reported (Bousfield 1952, Standing 1980, Grosberg 1982). Second, high levels of pre- or post-settlement larval mortality may reduce the number of recruits into the offshore population. Pre-settlement mortality could result from the ingestion of cyprids by acorn barnacles, conspecifics, and mussels. Cyprids and other crustacean remains are common in the guts of $P$. polymerus (Barnes 1959, Lewis 1981; up to 84 cyprids in 1 barnacle: Page unpubl.). Mussels may also ingest and damage larvae (Mileikovsky 1974, Peterson 1984). Since $\sim 95 \%$ of the pipe surface in the mid-intertidal zone was covered by large members of these species, ingestion could be an important source of larval mortality at Holly. Finally, a lack of suitable substrata for larval settlement may contribute to lower recruitment rates at Holly than at Goleta Pt.

Pollicipes polymerus can reach 20 to $26 \mathrm{~mm} \mathrm{CH}$ at Goleta Pt. (Fig. 4), but only a small percentage of the population attained these sizes (Fig. 1). The decrease in the number of individuals with increase in size (Fig. 1) indicates that barnacle mortality was size and/ or age dependent. The presence of newly exposed rock surface at the former sites of clumps indicated that the unstable substratum was an important source of mortality at Goleta Pt. Collins \& Le Mehaute (unpubl.) estimated that the soft shale rock of Goleta Pt. and the cliffs landward to Goleta Pt. were eroding several millimeters per year. The bases of the largest $P$. polymerus at Goleta Pt. were usually located in pholad bivalve Penitella penita holes suggesting that barnacles which settle in holes or crevices may live longer. In contrast to the shale rock of Goleta Pt., the metal support members at Holly provided a stable substratum for the attachment of $P$. polymerus. The bimodal population size structure at Holly was consistent through time: a strongly seasonal period of recruitment and/or growth, suggested by a movement of modes, was absent. I believe that the relative scarcity of $P$. polymerus in the intermediate sizes $(11$ to $22 \mathrm{~mm}$ $\mathrm{CH}$ ) at Holly is primarily due to the following. First, the stability of the substratum results in low mortality and a rapid individual growth rate (Fig. $4 \& 55$ ) has permitted the establishment of clumps of large individuals over an 18 yr period. Second, intraspecific competition restricts the growth of recent recruits and most may not achieve a size larger than $10 \mathrm{~mm} \mathrm{CH}$. The small barnacles, however, have the capability to increase in size when the large individuals are removed. The inhibition of growth of small $P$. polymerus among large barnacles could be due to reduced food availability. The large barnacles may interfere with the water flow which brings food to the small barnacles. The large $P$. polymerus surrounding the Treatment plot in the competition experiment may have contributed to a slower growth rate of small barnacles than that predicted from Fig. 5. The growth curves in Fig. 5 are most accurate for barnacles not experiencing intraspecific competition. Kantsky (1982) found that the growth of small mussels (Mytilus edulis $<2 \mathrm{~mm}$ in length) was suppressed by large mussels. This resulted in the presence of mussels $<2 \mathrm{~mm}$ all year round in the Baltic Sea despite a seasonal period of recruitment. In caging experiments, the degree of suppression of growth of these small mussels increased with increased density of large mussels (Kantsky 1982).

In conclusion, although the large size attained by some species on the supports of oil platforms has been noted by previous authors (Bascom et al. 1976, Simpson 1977, Wolfson et al. 1979), the present study is the first to simultaneously compare the population characteristics of a given species between proximal inshore and offshore locations. The factors which enhance the growth and survival of platform Pollicipes polymerus may similarly influence these characteristics in other invertebrate species at the same offshore location.

Acknowledgements. I thank J. Dugan, D. Hubbard, J. O'Brien, A. Wenner, and S. Willason for comments on the manuscript. I also thank D. Hubbard for assistance in the field. This work was supported by grants \#167-84 and \#74784 from the Atlantic Richfield Company and by computer funds from the Marine Science Institute. 


\section{LITERATURE CITED}

Barnes, H. (1956). The growth rate of Chthamalus stellatus (Poli). J. mar. biol. Ass. U.K. 35: 355-361

Barnes, H. (1959). Stomach contents and microfeeding of some common cirripedes. Can. J. Zool. 37: 231-236

Barnes, H., Barnes, M. (1956). The general biology of Balanus glandula Darwin. Pacif. Sci. 10: 415-422

Barnes, H., Barnes, M. (1968). Egg numbers, metabolic efficiency of egg production and fecundity: local and regional variations in a number of common cirripedes. J. exp. mar Biol. Ecol. 2: 135-153

Barnes, H., Powell, H.T. (1953). The growth of Balanus balanoides (L.) and $B$. crenatus Brug. under varying conditions of submersion. J. mar. biol. Ass. U.K. 32: 107-128

Barnes, H., Reese, E. S. (1959). Feeding in the pedunculate cirripede Pollicipes polymerus J. B. Sowerby. Proc. zool. Soc. Lond. 132: 569-585

Bascom, W., Mearns, A. J., Moore, M. B. (1976). A biological survey of oil platforms in the Santa Barbara Channel. J. Petrol. Technol. 28: 1280-1284

Bourget, E., Crisp, D. J. (1975). Factors affecting deposition of the shell in Balanus balanoides (L.). J. mar. biol. Ass. U.K. 55: 231-249

Bousfield, E. L. (1952). The distribution and spawning seasons of barnacles on the Atlantic coast of Canada. Annual Report of the National Museum, Canada, Bull. No. 132, p. $112-154$

Connell, J. H. (1961). The influence of interspecific competition and other factors on the distribution of the barnacle Chthamalus stellatus. Ecology 42: 710-723

Connell, J. H. (1970). A predator-prey system in the marine intertidal region. I. Balanus glandula and several predatory species of Thais. Ecol. Monogr. 40:49-78

Connell, J. H., Keough, M. J. (1985). Disturbance and patch dynamics of subtidal marine animals on hard substrata. In: Pickett, S. T. A., White, P. S. (ed.) Natural disturbance: The patch dynamics perspective. Academic Press, New York, p. 125-151

Crisp, D. J. (1960). Factors influencing growth-rate in Balanus balanoides. J. Anim. Ecol. 29: 95-116

Dayton, P. K. (1971). Competition, disturbance, and community organization: the provision and subsequent utilization of space in a rocky intertidal community. Ecol. Monogr. 41: 351-389

Ebert, T. A. (1968). Growth rates of the sea urchin Strongylocentrotus purpuratus related to food availability and spine abrasion. Ecology 49: 1075-1093

Fletcher, W. J. (1984). Intraspecific variation in the population dynamics and growth of the limpet, Cellana tramaserica. Oecologia (Berl.) 63: 110-121

Grosberg, R. K. (1982). Intertidal zonation of bamacles: the influence of planktonic zonation of larvae on vertical distribution of adults. Ecology 63: 894-899

Harger, J. R. E. (1970). The effect of wave impact on some aspects of the biology of sea mussels. Veliger 12: 401-414

Hines, A. H. (1976). Comparative reproductive ecology of three species of intertidal barnacles. Ph. D. dissertation, Univ. of California, Berkeley

Hines, A. H. (1979). The comparative reproductive ecology of three species of intertidal barnacles. In: Stancyk, S. E. (ed.) Reproductive ecology of marine invertebrates. University of South Carolina Press, Columbia, p. 213-234

Kantsky, N. (1982). Growth and size structure in a Baltic Mytilus edulis population. Mar. Biol, 68: 117-133

Lewis, C. A. (1981). Juvenile to adult shift in feeding strategies in the pedunculate barnacle, Pollicipes polymerus (Sowerby) (Cirripedia, Lepadomorpha). Crustaceana 41: 14-20

Lewis, C. A., Chia, F.-S. (1981). Growth, fecundity, and reproductive biology in the pedunculate cirripede Pollicipes polymerus at San Juan Island, Washington. Can. J. Zool. 59: 893-901

Mileikovsky, S. A. (1974). On predation of pelagic larvae and early juveniles of some marine bottom invertebrates by adult benthic invertebrates and their passing alive through their predators. Mar. Biol. 26: 303-311

Page, H. M. (1984). Local variation in reproductive patterns of two species of intertidal barnacles, Pollicipes polymerus Sowerby and Chthamalus fissus Darwin. J. exp. mar. Biol. Ecol. 74: 259-272

Paine, R. T. (1974). Intertidal community structure. Experimental studies on the relationship between a dominant competitor and its principal predator. Oecologia (Berl.) 15 93-120

Paine, R. T. (1976). Size-limited predation: an observational and experimental approach with the Mytilus-Pisaster interaction. Ecology 57: 858-873

Peterson, J. R. (1984). Larval settlement behavior in competing species: Mytilus californianus Conrad and $M$. edulis $\mathrm{L}$. J. exp. mar. Biol. Ecol. 82: 147-159

Rodhouse, P. G., Roden, C. M., Burnell, G. M., Hensey, M. P. McMahon, T., Ottway, B., Ryan, T. H. (1984). Food resource, gametogenesis and growth of Mytilus edulis on the shore and in suspended culture: Killary Harbour, Ireland. J. mar. biol. Ass. U.K. 64: 513-529

Sebens, K. P. (1982). The limits to indeterminate growth: an optimal size model applied to passive suspension feeders. Ecology 63: 209-222

Seed, R. (1968). Factors influencing shell shape in the mussel Mytilus edulis. J. mar. biol. Ass. U.K. 48: 561-584

Simpson, R. A. (1977). The biology of two offshore oil platforms. Institute of Marine Resources, University of California. IMB ref. 76-13

Sokal, R. R., Rohlf, F. J. (1981). Biometry. 2nd edition. W. H. Freeman and Co., San Francisco

Standing, J. D. (1980). Common inshore barnacle cyprids of the Oregonian faunal province (Crustacea: Cirripedia). Proc. Biol. Soc. Wash. 93: 1184-1203

Straughan, D. (1971). Breeding and larval settlement of certain intertidal invertebrates in the Santa Barbara Channel following pollution by oil. In: Straughan, D. (ed.) Biological and oceanographic survey of the Santa Barbara Channel oil spill 1969-1970. Vol. I. Allan Hancock Foundation, University of Southern California, Los Angeles, p. 223-244

Wolfson, A., Van Blaricom, G., Davis, N., Lewbel, G. S. (1979) The marine life of an offshore oil platform. Mar. Ecol. Prog. Ser. 1: 81-89 